\title{
International IP Licensing Transactions: Time to Adopt Global Rules for the Right of Exclusive Licensees to Sue for Infringement of the Licensed IP Rights?
}

\author{
Jacques de Werra
}

Published online: 20 April 2017

(C) Max Planck Institute for Innovation and Competition, Munich 2017

International IP licensing transactions are among the most common transactions in today's information-intensive, interconnected and dematerialized business environment. This may give the impression that the law governing such transactions is uniform and is largely independent from local regulations. This is, however, not the case. Local laws can particularly define under what conditions the licensed IP rights can be enforced against third-party infringers. ${ }^{1}$ This is obviously of key practical importance for the contracting parties, and specifically for an exclusive licensee who can expect to be in a position to fully benefit from its contractual exclusivity against third-party infringers.

Even if one could assume that the - quite standard - legal issue of the right to sue of the (exclusive) licensee for infringement of the licensed IP right is largely settled and uncomplicated, a look at a few recent court decisions rendered in various jurisdictions shows that there are still (too) many disputes on this matter. ${ }^{2}$ This is

\footnotetext{
1 See the Summary Report of AIPPI, Question Q190 Contracts regarding Intellectual Property Rights (assignments and licenses) and third parties, question 3, available at: https:/aippi.org/download/commitees/ 190/SR190English.pdf; see also all the country reports (study reports) available at: http://aippi.org/ committee/contracts-regarding-intellectual-property-rights-assignments-and-licenses-and-third-parties-2.

2 See e.g. in Australia: Bristol-Myers Squibb Company v. Apotex Pty Ltd [2015] FCR 2 (Austl.); in the European Union: CJUE, judgment of February 4, 2016, Hassan v. Breiding Vertriebsgesellschaft mbH (Case C-163/15) and judgment of June 22, 2016, Thomas Philipps GmbH \& Co. KG v. Grüne Welle Vertriebs GmbH (Case C-419/ 15); in Germany: Düsseldorf Court of Appeal, judgment of September 24, 2015 (Az. I-2 U 30/15); in India: Himalaya Drug Co. v. Arya Aushadhi Pharmaceutical Works, 1999 A.I.R.(M.P.) 110 (Madhya Pradesh High Court, February 19, 1999), Babul Products Private Ltd. v. Zen Products (Gujarat High Court, July 7, 2005), for a discussion of these cases, see Raman Mittal, "Trademark Transactions in India: Exploring the Genre, Scope and Consequence", in: Irene Calboli and Jacques de Werra (eds) The Law and Practice of Trademark Transactions, § 23.33-23.34 (Edward Elgar, 2016); in Switzerland: Swiss Federal Court, judgment of August 29, 2007 (ref. A_55/2007), sic! 2008, p. 209; in the United States of America (among many other cases): Luminara Worldwide, LLC. V. Liown Elecs. Co. (Fed. Cir. Feb. 29, 2016) (patent law).
}

J. de Werra $(\bowtie)$

Professor (intellectual property law and contract law), Vice-rector

University of Geneva, Geneva, Switzerland

e-mail: jacques.dewerra@unige.ch 
reflected in this very accurately entitled recent blog post: "The trademark licensing question that won't go away: the standing of a licensee to sue". ${ }^{3}$ This evidences the complexity of the local legal regimes that govern this issue (which may sometimes require the registration of the license in a local trademark registry). This complexity is further increased in the very common scenarios in which the license agreement covers multiple national (or regional) territories for which the licensed IP rights are governed by different national (or regional) IP laws. In such a scenario, the exclusive licensee may (or may not) have the right to enforce the licensed IP rights against third-party infringers depending on the application of diverging local regimes, whereby those regimes sometimes provide for different solutions depending on the types of licensed IP rights at issue. ${ }^{4}$ This fragmented approach clashes with the essence of global IP licensing transactions, which tends toward the adoption of a uniform regime. It further clashes with the legitimate expectations of the contracting parties to global IP licensing transactions who can reasonably expect that this issue will be addressed in a globally uniform manner, so that the exclusive licensee will (or not) have the right to sue for infringement in the licensed territories irrespective of the local laws of the countries in which protection would be sought. Can it be assumed that parties to a global exclusive licensing transaction covering say 15 countries should reasonably expect that the right of the exclusive licensee will depend on 15 different solutions resulting from 15 national (IP) laws and will not be governed by one single set of rules?

How should a uniform global system be structured? One could first of all consider that parties to an international IP license agreement should have the right and the freedom to decide if and under what conditions an exclusive licensee ${ }^{5}$ will have the right to sue third parties for infringement of the licensed IP rights as part of the principle of private autonomy. ${ }^{6}$ Local regulations should consequently not unduly affect this freedom of the contracting parties.

In the absence of solutions adopted by the parties, uniform global default rules defining the conditions under which an exclusive licensee shall have the right to sue for IP infringement could apply. Such default rules could provide that an exclusive licensee will have the right to sue after calling on the licensor to initiate infringement proceedings against the third-party infringers (in order to preserve the control of the licensor on litigation over its IP rights) and provided that the licensor had no valid reason for not initiating infringement proceedings against the

\footnotetext{
${ }^{3}$ http://ipkitten.blogspot.ch/2017/01/the-trademark-licensing-question-that.html (accessed January 26, 2017), which comments on the recent Indian decision of the Delhi High Court, P.K. Sen v. Exxon Mobile Corporation And Anr of January 4, 2017 (available at: https://indiankanoon.org/doc/119950261/).

${ }^{4}$ This is the case in some EU countries.

5 The very concept of what constitutes an exclusive license would also need to be defined consistently, whereby "it is true that merely terming a license agreement 'exclusive' is 'not conclusive as to its legal effect' if the actual rights granted under the agreement are inconsistent with the characterization" (Heraeus Kulzer LLC v. Omni Dental Supply, No. 12-11099-RGS (D. Mass. July 1, 2013)).

${ }^{6}$ This approach is based on the following paper of the author: "Can Exclusive Licensees Sue for Infringement of Licensed IP Rights?: A Case Study Confirming the Need to Create Global IP Licensing Rules", Harvard Journal of Law \& Technology, 2016-2017 special symposium issue, Private Law and Intellectual Property, pp. 189-208.
} 
third parties. ${ }^{7}$ The default rules could also provide that the exclusive licensee shall have the obligation to keep the licensor informed about the infringement proceedings. They could also address the financial consequences of the infringement proceedings that the exclusive licensee initiates.

The right of the exclusive licensee to sue for infringement is obviously just one of the numerous legal issues that can arise in connection with international IP licensing transactions. It is, however, quite emblematic because it evidences the tensions that can arise between global contractual deals and fragmented local IP solutions. It is therefore important to view this specific issue as reflecting a global phenomenon that should attract the attention of the IP community and that confirms that the time is ripe for the creation of global IP licensing policies.

\footnotetext{
7 This is the approach adopted in the most interesting Model Law on Intellectual Property Law: a Proposal for German Law Reform (Hans-Jürgen Ahrens and Mary-Rose McGuire), Abbreviated English Edition (2013) (based on the original German book: Modellgesetz für Geistiges Eigentum, Normtext und Begründung (2012), § 122 (title: "Licensee's right to sue in case of infringement”): "1 Without prejudice to the provision of the licence contract, the licensee may bring an action for infringement only if its rightholder consents thereto. ${ }^{2}$ However, the holder of an exclusive license may bring such proceedings if the rightholder, after formal notice, does not himself bring infringement proceedings within an appropriate period and the refusal of the consent, pursuant to sentence 1, is not justified according to the principle of good faith."
} 